\title{
Alternatives to the State: Or, Why a Non-Western IR Must Be a Revolutionary Science
}

Erik Ringmar

Ibn Haldun University

\begin{abstract}
The idea of the sovereign state is at the core of the Western understanding of international politics. If we are serious about coming up with non-Western theories of international politics, it is the state that must be questioned. This article suggests some ways in which this can be done. Only once we have unthought the state can we reconstruct international politics as a more equitable, and peaceful, world order.
\end{abstract}

Keywords: Non-Western IR theory, the state, empires, pan-Africanism, Ottoman Empire

The academic study of international relations is dominated by Western methods, theories and values. In the decades after the end of the Second World War, IR was all about how to avoid a nuclear showdown with the Soviet Union, how to organize a Western-led international system, and how to make sure that all poor, newly decolonized, countries became loyal members of it. Theories of international relations - Realism, Liberalism, Constructivism, and so on - were, despite their considerable differences, attempts to address the same, Western, concerns.

But times have changed. The memory of the Second World War is now fading fast and even the competition between the US and the USSR is starting to look remote. Instead new countries are on the rise - China, India, Brazil, even Turkey. These rising powers often have other concerns, other values, and other perspectives on relations between states. Not surprisingly, many have grown impatient with the academic study of international relations as it has been conducted up to now. Hence the demands for a new, non-Western, IR which can help make sense of the world to other people than Westerners. The only question is what such a non-Western IR possibly could be. Although suggestions certainly have been provided, there is no consensus on an answer and it is not clear how to proceed. As a result, even critics continue, despite themselves, to rely on the assumptions of the existing discipline. What indeed is the alternative? This is the question which will occupy us here. The conclusion which we will arrive at is that a more radical approach is called for. A non-Western IR must be a revolutionary science. That is, a non-Western IR must provide an alternative to the metaphor that has organized the academic study of international relations up to now - the notion of an anarchical system which takes the sovereign nation-state as its subject. The article concludes by suggesting a few alternatives to this Western prejudice.

Erik Ringmar, Professor, Department of Political Science and International Relations, Ibn Haldun University. Email: erik. ringmar@ihu.edu.tr. (D) 0000-0002-8110-6514. 


\section{The Problem of Political Independence}

On September 18, 1909, the English journalist G.K. Chesterton published an article in the Illustrated London News in which he discussed Indian nationalism. " "The principal weakness of Indian Nationalism," he wrote, "seems to be that it is not very Indian and not very national." What the Indian nationalists are saying is: ${ }^{2}$

Give me a ballot-box. Provide me with a Ministerial dispatch-box. Hand me over the Lord Chancellor's wig. I have a natural right to be Prime Minister. I have a heaven-born claim to introduce a Budget. My soul is starved if I am excluded from the Editorship of the Daily Mail.

The fact that the Indian nationalists want all these institutions, Chesterton concluded, is evidence that they really want to be English. As a result, "[w]e cannot feel certain that the Indian Nationalist is national". ${ }^{3}$ One of their publications is called the Indian Sociologist, he added. "It is all about Herbert Spencer and Heavens knows what. What is the good of the Indian national spirit if it cannot protect its people from Herbert Spencer? What are the young men of India doing that they allow such an animal as a sociologist to pollute their ancient villages and poison their kindly homes". ${ }^{4}$

M.K. Gandhi, who visited London in September 1909, read Chesterton's article when it first appeared and, according to a biographer, he was "thunderstruck" by the argument. When writing the introduction to an essay by Leo Tolstoy on Indian nationalism the same fall, Gandhi echoed Chesterton's conclusions. "India, which is the nursery of the great faiths of the world," as he put it,

will cease to be nationalist India, whatever else she may become, when she goes through the process of civilization in the shape of reproduction on that sacred soil of gun factories and the hateful industrialism which has reduced the people of Europe to a state of slavery, and all but stifled among them the best instincts which are the heritage of the human family. ${ }^{6}$

On his way back to South Africa by boat, Gandhi developed the argument in Hind Swaraj, the only book he ever wrote devoted to the topic of Indian independence. ${ }^{7}$ In order to obtain home rule, he insisted, we must first make sure that we have a home which is truly our own. ${ }^{8}$

This is a fundamental point which many Indian nationalists have forgotten. They want the tiger's nature, but not the tiger. That is, they want to make India English, but if that comes to pass it will no longer be "Hindustan" but instead "Englistan."

For a country to be truly independent, it must be defined in independent terms. India must be herself, not a version of Britain. Starting from this premise, the rest of the book is an elaboration on what home rule, in the true sense of the word, really means.

This is the argument that Ashis Nandy picked up, and gives a psychoanalytical twist, in his The Intimate Enemy: Loss and Recovery of Self under Colonialism, published in 
1989. ${ }^{9}$ A country which frees itself on someone else's terms, Nandy concludes, is never going to be truly free. The rhetoric of the first generation of nationalist leaders - in India and elsewhere - may have sounded anti-European, but in practice they were in cahoots with their former colonial masters. The nationalists grabbed power for themselves while promising to perpetuate the European model. There were, for a while, a few dissenting voices who advocated alternative solutions, but it was always clear that the Europeans only would grant sovereignty to states that were similar to their own, and to leaders who had gone to European schools and spoke European languages. As soon as the first generation of nationalist leaders had taken control of their respective countries, including their military and natural resources, there was no going back. This is how all independent states came to have their own territories and fortified borders; their capitals, armies, foreign ministries, flags, national anthems, and all the other paraphernalia of European statehood. From now on the political struggles concerned who should control the sovereign state, but the notion of sovereign statehood itself could no longer be questioned.

The world as it existed before the Europeans colonized it had not been organized in the European manner, and as a result there was at the time of decolonization no pre-existing nation-states waiting to become independent. The European carve-up of the world had created territories which had little or nothing to do with pre-colonial boundaries. Instead the sovereign states had to be "built," and soon scores of development experts descended on the capitals of the non-Western world dispatching advice on "state-building." Likewise, there were few "nations." There were "clans," "tribes" and "ethnic communities" to be sure, but there were next to no nations such as Europeans defined them. As a result, there was no political subject who could use the state to express its aspirations. Instead what the Europeans referred to as "tribalism" always threatened to tear the state apart. The development experts were thus forced to give advice on "nation-building" too. In fact, the twin-projects of state and nation-building have kept both political leaders and development experts busy for the last fifty plus years. They are still busy at it.

This is how a form of neo-imperialism was incorporated into the post-colonial world. Dependence was built into the system of independence. By modeling itself on European examples, an independent country would at best become a slightly inferior version of the real thing. At worse, the result would be a "failed state" - a state without functioning government, no proper administration, and no monopoly on the legitimate use of violence. A failed state, that is, is a state that is unable to live up to European standards. But why on earth should a non-European state be able to successfully emulate a European one? The task is difficult enough under the best of circumstances, but impossible if the population is destitute, the country is rich in natural resources, and power and wealth belong to the warlords with the biggest guns. Non-Europeans are not very good at being European. Europeans, let's face it, are so much better at it.

But there were successful cases too, to be sure - states like Israel, Turkey and China PRC. These were powerful states and they created nations for themselves which were no less viable than their European counterparts. In each case, however, a high price was paid for these achievements. In the struggle for statehood, other political entities were wiped out, peoples were displaced and genocides committed. Thus there is today a Turkey but no

9 Ashis Nandy, The Intimate Enemy: Loss and Recovery of Self Under Colonialism (Oxford: Oxford University Press, 1989). 
Kurdistan, an Israel but no Palestine, a China but no Uyghuristan or Tibet. And yet the losers in these struggles did not quietly go away but have continued to insist on their political rights ever since. The conflicts caused in this way cannot be solved since the European conception of statehood does not allow for two different states to exist on the same territory at the same time. Moreover, the nations that were created by these successful states were nothing but simplified, superficial, cartoons. Thus in the case of Turkey, the rich traditions of Islam and the Ottomans were replaced by Atatürkism; in the case of Israel, the Yiddish traditions of Europe and the Mizrahi and Sephardic traditions of Spain, North Africa and the Middle East were replaced by Zionism; and in China, Confucian morality and the whole legacy of the imperial tradition were rejected in favor of Marxism and the Maoist personality cult.

\section{The Problem of Intellectual Independence}

There is a problem of intellectual independence that accompanies the problem of political independence. By taking the European nation-state as the unexamined presupposition of their analyses, non-Western scholars of international relations are forced to start from European assumptions. Such a non-Western IR will never be truly independent, and the scholars who practice it will be like the nationalists who Chesterton, Gandhi and Nandy discussed - they too want to get rid of the tiger while appropriating the tiger's nature. Western IR is not wrong, they argue, but unfair. What they want is not really a different kind of IR, but instead an IR in which they themselves play a more prominent role. This, paraphrasing Chesterton, is what they say:

Give me a tenured position at an Ivy League university. Make me key-note speaker of the international conference. I have a natural right to be president of the International Studies Association. I have a heaven-born claim to run the CUP book series. My soul is starved if I am excluded from the editorship of International Organization.

These are certainly legitimate demands. There is no doubt that non-Western scholars are underrepresented in the academic study of international relations. And yet, this is also one of the ways in which the Western intellectual hegemony over the discipline is maintained.

Slightly differently put, the problem is that non-Western IR scholars are forced to make concessions to what Thomas Kuhn in The Structure of Scientific Revolutions, 1962, referred to as a "normal science". ${ }^{10}$ You cannot do science alone, you need collaborators, but for collaboration to be possible there must be common standards and assumptions; there must be people who work on the same problems, in the same way, and who communicate with each other by means of a shared vocabulary. This is what a normal science provides. Normal science is made up of the assumptions, theories, methodologies, received opinions and standard operational procedures that scientists rely on in their daily work. Given that research always is supposed to be innovative and "path-breaking," it is easy to make fun of normal science, yet there would be no science without it. If you want to make a contribution, it must be made to a normal science.

Differently put, your discipline disciplines you. Or, to be more precise, by subjecting yourself to a normal science, you come to discipline yourself. Unless you do what you are expected to do, you will never have a career, get into print or be invited to conferences. And, the more marginal you are in relation to a normal science, the more eagerly you are likely to 
subject yourself to its requirements. It is only by behaving yourself according to the standards of your discipline that you will be taken seriously by your colleagues. This in the end is the social logic which makes non-Western IR scholars conform. A non-Western IR which is at odds with normal science will always look unnormal, that is, amateurish or simply as incorrect.

A normal science, Kuhn continued, is united around a "paradigm". ${ }^{11}$ Although Kuhn himself was notoriously imprecise in his definition of this concept, we could think of paradigms as constructed around metaphors. ${ }^{12}$ Before a normal science can come to be established, the field we study must first be configured as a field of a certain kind. This is what metaphors do. A metaphor provides us with an ontology; it opens up a certain world, which we go on to explore. Normal science proceeds as we investigate the entailments which a certain metaphor makes available. The study of international relations illustrates the logic. In Western IR the metaphor of an "anarchical system" provides the ontology from which normal science proceeds. ${ }^{13}$ International politics, normal IR scholarship tell us, is made up of sovereign units - "states" — which act independently of each other, but whose interactions at the same time influence whatever they do. An anarchical system consists of interacting, self-directing, parts. Exploring this metaphor, scholars soon come up with any number of entailments - they talk about "security dilemmas," "arms races," "balances of power," "collective action problems," and so on.

But, as we pointed out, this description never fit the world as it had existed outside of Europe before the era of colonization. In the rest of the world, there were no European-style states and no European-style nations. Instead both had to be created, and these creations often failed. As a result, the master metaphor of the anarchical state system was never able to properly describe an existing, non-European, empirical reality. Instead, it was empirical reality that had to be rearranged in order to fit the requirements of the metaphor. If there was a mismatch between the two, IR scholars and development experts concurred, it was reality, not the theory, which was at fault. This was, it should have been obvious, not an attempt to study the world, that is, but instead an attempt to radically transform it. By applying the master metaphor of an anarchical system of sovereign states, an international system which did not exist was going to be created. The world was to be remade in the West's image.

At the time of decolonization, some Western IR scholars worried that academics in the newly independent states would fail to behave as they were expected. ${ }^{14}$ Perhaps non-Western IR scholars would start insisting on some alternative, non-Western, way of conceptualizing international politics? Perhaps they would seek to question, and undermine, the master metaphor which guided the discipline? Yet, as it turned out, there was no need to worry. Non-Westerner IR scholars were always prepared to discipline themselves. They too, after all — just like the new generation of nationalist leaders who ran their countries — stood to gain from their subordination to the Western model. It was by providing intellectual support for their respective state and nation-builders that non-Western IR scholars assured careers, and prestige, for themselves. Occasionally, they would even be invited to contribute to the

\footnotetext{
11 Kuhn, The Structure of Scientific Revolutions.

12 George Lakoff and Mark Johnson, Philosophy in the Flesh: The Embodied Mind and Its Challenge to Western Thought (New York: Basic Books, 1999).

13 Michael P. Marks, Metaphors in International Relations Theory (Basingstoke: Palgrave Macmillan, 2011).

14 Hidemi Suganami, "British Institutionalists, or the English School, 20 Years On," International Relations 17, no. 3 (2003): 253-72; Charles A.W. Manning, The Nature of International Society (London: Macmillan, 1975).
} 
discipline as it was practiced in the West. This is how non-Westerner IR scholars condemned themselves to a subordinate position. This is also how non-Western academia came to be filled with failed attempts to emulate Western models. Not surprisingly, the non-Western world is littered with failed Harvards. Harvard, on the whole, is far better at being Harvard than any of the universities we find in the non-Western world.

\section{Alternatives to the Nation-State}

A genuinely non-Western IR must start from a different premise. The metaphor of an anarchical system is derived from European experiences and European history, we said; it was in Europe and nowhere else that an anarchical system of sovereign states came to be established. Other, non-European, international systems have been organized in different ways, with other norms, rules and institutions. There are other metaphors, that is, around which an alternative normal science could be organized. Such a substitution of one master metaphor for another is what Kuhn referred to as a "revolutionary science" - "those noncumulative developmental episodes in which an older paradigm is replaced in whole or in part by an incompatible new one". ${ }^{15}$ A truly independent, non-Western, IR should aim to bring about such a substitution. A non-Western IR must be a revolutionary science.

History should be our inspiration here. The past is a different country and it was organized in different ways. This includes its international relations. Thus, we have much to learn inter alia from the tribute system of imperial China, from the relations that obtained between the Yoruba city-states, and from the logic of the empires constructed by the Aztecs, the Mongols and the rulers of Mali. ${ }^{16}$ These international systems were not necessarily more peaceful than the European system, but they were different, and by learning more about them, we will come across alternative ways of conceptualizing international politics. But the present has much to teach us too. Here we should let the "failed states" show us the way. By understanding why states "fail," we will learn more about alternatives to Western conceptions. What looks like a failure, that is, can often be understood as an alternative, non-Western, way of organizing social and political relations. And then there is the future. Globalization - the trans-border flow of ideas, images, technologies, people, drugs, disease, money, weapons and pollution - means that states no longer can control their borders, run their economies autonomously, or shield their citizens from outside threats. States are surely not about to disappear, but sovereignty - their most vaunted possession — is in rapid decline.

So what are the alternatives to the state and to the anarchical state system? These are some suggestions.

\subsection{Stateless societies}

Today the world is completely divided up between political entities. All territory belongs to one state or another and no land belongs to more than one state. States are mutually exclusive and together exhaustive of political space. Yet this has not always been the case. It was only as a result of the introduction of farming some 12,000 years ago that the first states appeared. ${ }^{17}$ Before that, during some 95 percent of human history, we were hunters and gatherers who moved around in response to the seasonal variations in the availability of food. And even

15 Kuhn, The Structure of Scientific Revolutions, 92.

16 Erik Ringmar, History of International Relations (Cambridge: Open Book Publishers, 2019).

17 James C. Scott, Against the Grain: Plants, Animals, Microbes, Captives, Barbarians, and a New Story of Civilization (New Haven: Yale University Press, 2017). 
after the introduction of farming, there were pastoralists. Since pastoralists continuously move their animals from one pasture to another, they have little respect for borders and are difficult for political authorities to control. It was only late in the nineteenth-century that the government of the United States finally subdued the Native Americans and that the Chinese government was able to police its borders with Mongolia. ${ }^{18}$ Yet there are still pastoralists in the world today; indeed, there are still societies of hunters and gatherers.

Somalia is everyone's favorite example of a "failed state," yet the country has strong nomadic traditions which continue to provide order, justice and security even in the absence of a state. ${ }^{19}$ Rather than fixing the failed state which is Somalia, perhaps it is the institutions of nomadic society that should be restored? This suggestion goes against the well-established prejudice which says that nomads represent a prior, and thereby inferior, stage in human history, one that inevitably must disappear. But what if this is not the case? After all, the lives of most of us are daily becoming more, not less, nomadic. Pushed and pulled by the forces of global capitalism, we too are increasing required to move around in order to make a living for ourselves. As a result, new kinds of political institutions are required - political institutions which we can take with us we cross borders. By learning more about nomadic societies, we learn more about how stateless societies function. ${ }^{20}$ In this way the nomads of the past can provide advice to the nomads of the future. The pastoralists of Somalia are us.

\subsection{Thalasocracies}

Not all political entities have a territorial base, some are based on water. From thalassa, the Greek for "sea," and kratos, "power," a "thalasocracy" is a political entity that stretches out across water rather than land. The Phoenician and the Minoans were thalosocracies, and so were the classical Greek city-states and Carthage, Rome's foe. Southeast Asia too has had plenty of thalasocracies, including Srivijaya and Majapahit, two flourishing kingdoms based in the archipelago of today's Indonesia. ${ }^{21}$ In the absence of agriculture, the power of thalasocracies is founded on trade. It is by encouraging exchange, and controlling trade routes, that they grow rich. This also means that thalasocracies are quick to pick up on influences coming from outside, and as such they often serve as examples to others. This is also how the Greek city-states — fanning out across the eastern Mediterranean — picked up influences from Egypt, the Near East and beyond. ${ }^{22}$

Thalasocracies operate according to a different logic than agriculturally-based states. Thalasocracies can be immensely powerful, but they make no claim to sovereignty. They cannot insist on the inviolability of their borders since there have none; they are also impossible to invade since they have no territorial extension. Thalasocracies are not boxes with an inside and an outside, instead they are networks made up of nodes. If one of its

18 Owen Lattimore, "The Outer Mongolian Horizon," in Studies In Frontier History: Collected Papers, 1928-1958 (Oxford: Oxford University Press, 1962), 259-69.

19 Jamil A. Mubarak, "The 'Hidden Hand' behind the Resilience of the Stateless Economy of Somalia," World Development 25, no. 12 (1997): 2027-041; Ken Menkhaus, "Traditional Conflict Management in Contemporary Somalia," in Traditional Cures for Modern Conflicts: African Conflict "medicine”, ed. Ira William Zartman (Boulder: Lynne Rienner Publishers, 2000), 183-200.

20 Erik Ringmar, "Order in a Borderless World: Nomads Confront Globalization," in Theorizing Global Order: The International, Culture and Governance, ed. Gunther Hellman (Frankfurt: Campus, 2018).

21 Oliver W. Wolters, History, Culture, and Region in Southeast Asian Perspectives (Ithaca, N.Y: Southeast Asia Program Publications, Cornell University, 1999).

22 Arnaldo Momigliano, "Sea-Power in Greek Thought," The Classical Review 58, no. 1(1944): 1-7; Kostas Vlassopoulos, "Between East and West: The Greek Poleis as Part of a World-System," Ancient West and East 6 (2007): 91-111; John Watson McCrindle, The Commerce and Navigation of the Erythraean Sea: Being a Translation of the Periplus Maris ... (London: Thacker, Spink \& Co., 1879). 
cities is destroyed, resistance can continue from another city in the network. The map of a thalasocracy looks like a subway map - it tells us exactly how to get from point A to point $\mathrm{B}$, but it provides next to no geographical information. ${ }^{23}$ Instead the power of a thalasocracy rests on its navy. It was sea power which allowed the Vikings of Scandinavia to make their annual trips to England to collect taxes, and which much later allowed the English to keep their world-wide empire together. ${ }^{24}$ For a non-Western IR that is looking for alternative ways of conceptualizing international politics, thalasocracies provide plenty of suggestions.

\subsection{Stadtluft macht frei}

Another alternative to the sovereign state is the self-governing city. Cities, from the ancient Greeks onward, have often been independent, with its inhabitants — the "citizens" — taking an active part in the running of their common affairs. Cities are often republics and proud of their liberties. In addition, cities are commercial hubs, and the burghers - the merchant classes - play a prominent social and political role. Since commerce requires partners, cities have established links with other cities, creating networks which resemble those of thalasocracies. Cities too are nodes in commercial networks. A good example are the cities that thrived on the east coast of Africa between the tenth and the fifteenth centuries CE. ${ }^{25}$ Cities such as Kilwa Kisiwani, Malindi, Mombasa and Zanzibar, were founded by merchants from Oman and Persia, but it was by means of African traders that gold and ivory came to be exported to every conceivable location around the Indian Ocean. ${ }^{26}$ Shards of Chinese pottery have been found in Kilwa and coins minted in Kilwa have turned up in Australia.

Trade can only flourish if one's partners can be relied on to deliver goods and pay debts; there must be common standards of weights and measurements; a way to translate prices between different currencies; and procedures for drawing up, and enforcing, commercial contracts. In the absence of a sovereign state it is not clear how this can be achieved. And yet, networks of cities have often overcome such challenges. Through repeated interaction, the commercial connections gradually come to be overlaid with networks of trust. ${ }^{27}$ On this basis, medieval European merchants, such as the members of the Hanseatic League, established a Lex mercatoria, a merchants' law, with courts that adjudicated cases in the absence of a sovereign power. ${ }^{28}$ In Italy, in particular, cities have remained important to this day, and they are arguably still a main source of identity and allegiance..$^{29}$ Likewise, Londoners, New Yorkers, Shanghainese and Istanbulites have far more in common with each other than they do with people in the countryside that surrounds their cities. ${ }^{30}$

\subsection{A new Ottoman Empire}

The European idea of the nation-state has had particularly disastrous consequences in the

23 Donald Wigal, Historic Maritime Maps Used for Historic Exploration, 1290-1699 (New York: Parkstone, 2000).

24 Alfred Thayer Mahan, The Influence of Sea Power Upon History 1660-1783 (Boston: Little Brown\& Co.,1892).

25 Chapurukha M. Kusimba, The Rise and Fall of Swahili States (Walnut Creek: Altamira Press, 1999).

${ }^{26}$ François-Xavier Fauvelle, The Golden Rhinoceros: Histories of the African Middle Ages (Princeton: Princeton University Press, 2018).

${ }_{27}$ Charles Tilly, "Cities, States, and Trust Networks: Chapter 1 of Cities and States in World History," Theory and Society 39, no. 3-4 (2010): 265-80; Wim Blockmans, "Inclusiveness and Exclusion: Trust Networks at the Origins of European Cities," Theory and Society 39, no. 3-4 (2010): 315-26.

28 Keith Highet, "Enigma of the Lex Mercatoria," Tulane Law Review 63 (1988): 613-28; Friedrich K. Juenger, "The Lex Mercatoria and Private International Law," Louisiana Law Review 60 (1999): 1133-150.

29 Giorgio Chittolini, "The "Private " the "Public," the State," The Journal of Modern History 67 (1995): 34-61.

30 Saskia Sassen, Global Networks, Linked Cities (London: Routledge, 2016) 
case of the Middle East. A part of the world with plenty of ancient history, the Middle East has more than its fair share of religions, languages and ethnic groups. It was this intricate pattern that nationalism set out to simplify. Arab, Turkish and Israeli nationalism destroyed ancient communities, led to state repression, genocides, expulsions and war - not least once the two superpowers during the Cold War decided to support the nationalist regimes. ${ }^{31}$ By contrast, the Ottoman Empire - the international system that preceded the nationalist era - was both more pluralistic and less repressive. ${ }^{32}$ The Ottoman Empire was made up of a multitude of different peoples, each ruled by its respective civil codes. ${ }^{33}$ The fact that the Ottoman Empire was so large, its constituent parts so difficult to control, and that during its last hundred years it was in economic decline, allowed for a great measure of political independence within the imperial structures.

Imagine a world in which the Ottoman Empire was not abolished in 1923, or a world in which a political structure such as the Ottoman Empire could be recreated. ${ }^{34}$ Here people of different ethnicities would be able to share the same political space, and everyone would get to live in the country of their imagination. A Jew could easily imagine herself living in Israel, while her Palestinian neighbor could imagine himself living in Palestine. ${ }^{35}$ And some, perhaps, would once again identify themselves as Ottoman. In addition, an updated version of the Ottoman Empire would provide far better protection for persecuted minorities like the Yazidis, Mandaeans, Samaritans, Zoroastrians and the Copts; and Jewish culture would still flourish in Cairo, Istanbul and Baghdad. ${ }^{36}$ Moreover, the oil wealth of the Arabian peninsula would no longer prop up repressive regimes, and put money in the pockets of Western arms manufacturers, but instead benefit the peoples of the empire as a whole.

\subsection{Pan-nationalism}

During the 1950s and 60s, there were still those who argued that the former colonies should not form nation-states of their own but instead unite into larger political entities. Pan-Arabism advocated unity for all Arabs, and Pan-Africanism unity for Africans; there have even been advocates of Pan-Turkism. ${ }^{37}$ Only in this way, the argument went, would the former colonies be strong enough to stand up to the West. This project too was nationalistic, in other words, but the nations in question were far larger than the nationalism pertaining to individual colonies. The pan-movements were secular and they often embraced socialist principles. PanAfricanism was officially endorsed by leaders such as Kwame Nkrumah in Ghana and Julius Nyerere in Tanzania. ${ }^{38}$ "For it was as Africans that we dreamed of freedom," as Nyerere put it in 1966. "Our real ambition was African freedom and African government. The fact that we

\footnotetext{
31 Elie Kedourie, Nationalism (Oxford: Blackwell, 1993).

32 Selim Deringil, The Well-Protected Domains: Ideology and the Legitimation of Power in the Ottoman Empire, $1876-1909$ (London and NY: I. B. Tauris, 1999).

33 Karen Barkey and George Gavrilis, "The Ottoman Millet System: Non-Territorial Autonomy and Its Contemporary Legacy," Ethnopolitics 15, no. 1 (2016): 24-42.

34 Daniel Pipes, Greater Syria: The History of an Ambition (Oxford: Oxford University Press, 1992).

35 Dmitry Shumsky, Beyond the Nation-State: The Zionist Political Imagination from Pinsker to Ben-Gurion (New Haven: Yale University Press, 2018); Moshe Berent, A Nation like All Nations: Towards the Establishment of an Israeli Republic (New Rochelle: Israel Academic Press, 2015).

36 Gerard Russell, Heirs to Forgotten Kingdoms: Journeys Into the Disappearing Religions of the Middle East (New York: Basic Books, 2014).

37 Hakim Adi, Pan-Africanism: A History (London: Bloomsbury Academic, 2018); Tawfic E. Farah, Pan-Arabism and Arab Nationalism: The Continuing Debate (Oxon and New York: Routledge, 1987); Jacob M. Landau, Pan-Turkism: From Irredentism to Cooperation (London: C. Hurst \&Co., 1995).

38 Adi, Pan-Africanism.
} 
fought area by area was merely a tactical necessity". ${ }^{39}$

A few attempts at political unification were indeed undertaken. Egypt and Syria were officially united into the United Arab Republic between 1958 and 1961; Jordan and Iraq were united for six months in 1958; and Kenya, Tanganyika, Uganda and Zanzibar held discussions about a union in the early 1960s. ${ }^{40}$ Yet in the end, the pan-nationalisms were powerless against the nationalisms of the nation-states. State-nationalisms gave power total, sovereign, power - to those who controlled them, whereas the pan-nationalisms gave access to no political or military structures. The rhetoric of unity has survived, but it is today mainly reserved for speeches at the meeting of the Arab League and the African Union.

The petty nationalisms of the nation-states are a betrayal of the promise of these far larger communities, yet this is not to say that people in Africa or the Arab world have stopped thinking of themselves as members of them. Borders both in Africa and in the Arab world are still porous, and influences spread quickly from one location to the next. Witness the rapid dissemination of pro-Nasser enthusiasm in the 1950s, the impact of the Islamic revolution in Iran in $1978 / 79$, or the Arab Spring of $2011 / 12 .{ }^{41}$ Or consider a political entity such as ISIS, or an organization such as Al-Qaeda, that appeals to loyalties that transcend the nationstate. ISIS and Al-Qaeda are unacceptable responses to these sentiments, but the pan-national loyalties remain - and are still waiting for a political expression. And yet, the old pannationalisms are no doubt in need of an update before they are ready for the twenty-firstcentury. For one thing they cannot embrace the original, simple-minded, version of socialism, and pan-Arabism possibly cannot embrace secularism either.

\subsection{The failed states of Europe}

State failures do not only happen in poor countries in Africa; they happen in Europe too. Indeed, the European Union is premised on state failure. The aim of the EU, as it originally was conceived, was to provide a supra-national institutional framework which could deal with the failure of European states to live in peace with each other. State sovereignty, as the two world wars amply had demonstrated, was a disaster, and the EU was designed to limit and control it. If the idea of a sovereign state actually would have worked, no EU would have been needed.

More recently, the challenges posed by globalization have provided an additional rationale for supra-nationalism. While European states remain, their borders have become increasingly permeable, and this has resulted in a loss of control. Sovereignty, if it is to mean anything at all, must be pooled. The EU can set food standards, limit the power of Internet companies, and deal with global warming and border-transgressing pandemics in a way that none of its member states can. The individual nation-states have failed once again, and that is why the EU is needed. In a referendum on June 23, 2016, a majority of the people of Great Britain rejected this argument, insisting that state sovereignty still is a viable option. Whether they are right or wrong remains to be seen. Meanwhile, support for EU membership is increasing in the rest of Europe. ${ }^{42}$

\footnotetext{
150 .

39 Daryl Zizwe Poe, Kwame Nkrumah's Contribution to Pan-Africanism: An Afrocentric Analysis (London: Routledge, 2003),

40 Carl Gustav Rosberg and Aaron Segal, “An East African Federation,” International Conciliation no. 543 (1963): 5-72.

${ }^{41}$ Abdullah Enes Tüzgen, "Normative Consensus and Regional Orders: Saudi Reaction to Systemic Crises in the Middle East" (Ph.D. diss., University of Delaware, Newark, 2019); Ty Solomon, "Ontological Security, Circulations of Affect, and the Arab Spring," Journal of International Relations and Development 21 (2018): 934-58.

42 “Our Data," Europe Elects (blog), 2019, accessed June 24, 2019, https://europeelects.eu/data/.
} 
In fact, the EU too can be understood as a return to an earlier form of political organization. The international system of the European Middle Ages was not made up of sovereign states after all, but of political entities of many different kinds which were united in a continentwide community. Most of life was local, and highly diverse, but medieval culture was also strikingly uniform - united around a shared set of religious beliefs and one language of learning. It was this pluribus unum which was destroyed by the establishment of the sovereign state in the early modern era. ${ }^{43}$ Closing this parenthesis - putting an end to the age of the sovereign state - the EU constitutes a return to the normal, and far more viable, pattern of political interaction. The essentially decent, rather incompetent, imperialism of the European Union represents the best hope for world peace.

\subsection{A politically correct colonialism}

The anarchical system of sovereign states does not only result in inter-state warfare but it also makes domestic atrocities possible. The doctrine of non-interference in the "internal affairs" of each state gives protection to dictators who commit crimes against their own populations. The list of genocides is long, sad, and well-known. Recently the idea of non-interference has been questioned by those who argue that the world community has a "responsibility to protect" those who are subject to atrocities, even if this means violating state sovereignty. ${ }^{44}$ It is thus thought legitimate to invade a country as long as it prevents or stops a far greater harm. Such "liberal interventions" are controversial since there always is a suspicion that they are undertaken for less than perfectly altruistic motives. This is particularly the case since it is always Western countries that intervene in non-Western countries.

Liberal interventions, and the responsibility to protect, resemble colonialism, which also took place behind a smokescreen of benevolence. Outside of Europe, the memory of colonialism is still strong, and often actively rekindled by nationalist leaders. The colonies were exploited economically, their traditional ways of life destroyed, and their inhabitants mistreated. Yet what still hurts more than anything is the condescension of the Europeans. Everywhere they went, the Europeans were convinced that they were superior to the natives. It is this attitude that nationalist leaders still refer to in their rhetoric. Indeed, anti-colonial resentment still provides a main basis of their support. And yet, a case can be made for a new form of colonialism - a politically correct colonialism without condescension, based on civil liberties and democratic ideals, and not necessarily undertaken by Europeans. ${ }^{45}$ If self-determination equals atrocities and genocide, alternative political arrangements condominia, protectorates, mandates, trusteeships, federations, partnerships, affiliations will suddenly become far more attractive. The intervention of the African Union in Sudan, 2004-07, and Somalia, 2007-present; and the UN administration of Kosovo, 1999-2008 and Cambodia, 1992-93, provide possible models, yet there is no reason why such arrangements should be only temporary. There are parts of the United States that would benefit enormously from international supervision. A politically correct form of neocolonialism too provides an alternative to the European state-system.

43 Michael Massing, Fatal Discord: Erasmus, Luther, and the Fight for the Western Mind (New York: Harper, 2018).

44 Cristina Gabriela Badescu, Humanitarian Intervention and the Responsibility to Protect: Security and Human Rights (London: Routledge, 2012).

45 Rosa Ehrenreich Brooks, "Failed States, or the State as Failure?," The University of Chicago Law Review 72, no. 4 (2005): $1186-87$. 


\section{Conclusion}

The academic study of international relations is dominated by Western methods, theories and values, yet the rise of non-Western powers has increased the demand for non-Western perspectives. At the same time it is far from clear what a non-Western IR might be. The argument made in this article was that the non-West's intellectual dependence on the West parallels the non-West's political dependence. As Chesterton, Gandhi and Nandy have pointed out, a country which makes itself free on someone else's terms will never be truly free. Likewise, a non-Western IR which mimics Western models condemns itself to an inferior status. Western states are so much better at being Western states, and Harvard is so much better at being Harvard.

In both cases it is the uncritical acceptance of the master metaphor of an anarchical system made up of sovereign nation-states which is to blame. The former colonial masters were only ready to grant independence to political entities which resembled their own, and a new generation of nationalist leaders were quick to spot the advantages this presented. As leaders of independent states, they too were now going to be rich and powerful. The fact that few nation-states actually existed mattered less since both states and nations were to be "built." The normal science of international relations, as practiced in the West, proceeded on this basis. Yet the task was not to scientifically describe the world, but to create a world in the West's image. The non-Western IR scholars who lent their efforts to this project were complicit in the subjection of their discipline and in the subjection of their countries. But then again, they too benefited. They got tenured jobs in the leading universities of the newly independent states - and occasionally they were even invited to conferences in Europe and North America.

This is why a non-Western IR cannot be a normal, but must be a revolutionary, science. A truly independent non-Western IR must reject the attempt to create a world in the West's image. A non-Western IR must reject the master metaphor of an anarchical state-system based on sovereign nation-states. There are, we suggested, a number of ways in which this can be done. There are alternatives to the nation-state. We can learn what these alternatives are by investigating the history of non-Western international systems, by following the lead of states that "fail" in our contemporary world, and by thinking about a future in which the idea of sovereignty is redundant. States are not about to disappear to be sure, but their sovereignty is rapidly dissipating. A revolutionary science of international relations is, arguably, also an exercise in world-making, but the world which it makes is more evenly balanced than the one in which we have lived for the past 400 years. It is also, at least potentially, a world which is more peaceful and just. The day when a revolutionary non-Western IR becomes the new normal science, we will all be living in a different, and better, world.

\section{Acknowledgements}

I am grateful to the participants in the $4^{\text {th }}$ All Azimuth Workshop, "Dialogue in Core-Periphery IR," held in Istanbul May 17-18, 2019, and in particular to Deniz Kuru. Thanks to Gal Levy for help with references and to James C. Scott for historical examples. As always the work of the indefatigable librarians at Internet Archive and Library Genesis proved invaluable. 


\section{Bibliography}

Adi, Hakim. Pan-Africanism: A History. London: Bloomsbury Academic, 2018.

Badescu, Cristina Gabriela. Humanitarian Intervention and the Responsibility to Protect: Security and Human Rights. London: Routledge, 2012.

Barkey, Karen, and George Gavrilis. "The Ottoman Millet System: Non-Territorial Autonomy and Its Contemporary Legacy." Ethnopolitics 15, no. 1 (2016): 24-42.

Berent, Moshe. A Nation like All Nations: Towards the Establishment of an Israeli Republic. New Rochelle: Israel Academic Press, 2015.

Blockmans, Wim. "Inclusiveness and Exclusion: Trust Networks at the Origins of European Cities." Theory and Society 39, no. 3-4 (2010): 315-26.

Brooks, Rosa Ehrenreich. "Failed States, or the State as Failure?" The University of Chicago Law Review 72, no. 4 (2005): 1159-96.

Chesterton, G. K. "Matthew Arnold, among Much That Was Arid and Arbitrary..." Illustrated London News, September 18, 1909.

Chittolini, Giorgio. "The "Private " the "Public," the State." The Journal of Modern History 67 (1995): 34-61.

Deringil, Selim. The Well-Protected Domains: Ideology and the Legitimation of Power in the Ottoman Empire, 1876-1909. London and NY: I. B. Tauris, 1999.

Farah, Tawfic E. Pan-Arabism and Arab Nationalism: The Continuing Debate. Oxon and New York: Routledge, 1987.

Fauvelle, François-Xavier. The Golden Rhinoceros: Histories of the African Middle Ages. Princeton: Princeton University Press, 2018.

Furbank, Philip N. "Chesterton, the Edwardian." In G.K. Chesterton: A Centenary Appraisal, edited by John Sullivan. London: HarperCollins, 1974.

Gandhi, Mohandas Karamchand. Hind Swaraj, or Indian Home Rule. Ahmedabad: Navajivan Publishing House, 2015.

—. "Introduction." In A Letter to a Hindu, by Leo Tolstoy. 19th November, 1909. https://www.gutenberg.org/ files/7176/7176-h/7176-h.htm

Green, Martin B. Gandhi: Voice of a New Age Revolution. Mount Jackson: Axios Press, 2009.

Highet, Keith. "Enigma of the Lex Mercatoria.” Tulane Law Review 63 (1988): 613-28.

Juenger, Friedrich K. “The Lex Mercatoria and Private International Law.” Louisiana Law Review 60 (1999): 1133150.

Kedourie, Elie. Nationalism. Oxford: Blackwell, 1993.

Kuhn, Thomas S. The Structure of Scientific Revolutions. 3rd ed. Chicago: University of Chicago Press, 1996.

Kusimba, Chapurukha M. The Rise and Fall of Swahili States. Walnut Creek: Altamira Press, 1999.

Lakoff, George, and Mark Johnson. Philosophy in the Flesh: The Embodied Mind and Its Challenge to Western Thought. New York: Basic Books, 1999.

Landau, Jacob M. Pan-Turkism: From Irredentism to Cooperation. London: C. Hurst \&Co., 1995.

Lattimore, Owen. "The Outer Mongolian Horizon.” In Studies In Frontier History: Collected Papers, 1928-1958, 259-69. Oxford: Oxford University Press, 1962.

Mahan, Alfred Thayer. The Influence of Sea Power Upon History 1660-1783. Boston: Little Brown\& Co.,1892.

Manning, Charles A.W. The Nature of International Society. London: Macmillan, 1975.

Marks, Michael P. Metaphors in International Relations Theory. Basingstoke: Palgrave Macmillan, 2011.

Massing, Michael. Fatal Discord: Erasmus, Luther, and the Fight for the Western Mind. New York: Harper, 2018.

McCrindle, John Watson. The Commerce and Navigation of the Erythraean Sea: Being a Translation of the Periplus Maris ... London: Thacker, Spink \& Co., 1879.

Menkhaus, Ken. "Traditional Conflict Management in Contemporary Somalia.” In Traditional Cures for Modern 
Conflicts: African Conflict “medicine”, edited by Ira William Zartman, 183-200. Boulder: Lynne Rienner Publishers, 2000.

Momigliano, Arnaldo. "Sea-Power in Greek Thought.” The Classical Review 58, no. 1 (1944): 1-7.

Mubarak, Jamil A. "The 'Hidden Hand' behind the Resilience of the Stateless Economy of Somalia." World Development 25, no. 12 (1997): 2027-041.

Nandy, Ashis. The Intimate Enemy: Loss and Recovery of Self Under Colonialism. Oxford: Oxford University Press, 1989.

Pipes, Daniel. Greater Syria: The History of an Ambition. Oxford: Oxford University Press, 1992.

Poe, Daryl Zizwe. Kwame Nkrumah's Contribution to Pan-Africanism: An Afrocentric Analysis. London: Routledge, 2003.

Ringmar, Erik. "Order in a Borderless World: Nomads Confront Globalization.” In Theorizing Global Order: The International, Culture and Governance, edited by Gunther Hellman. Frankfurt: Campus, 2018.

- History of International Relations. Cambridge: Open Book Publishers, 2019.

Rosberg, Carl Gustav, and Aaron Segal. “An East African Federation.” International Conciliation no. 543 (1963): $5-72$.

Russell, Gerard. Heirs to Forgotten Kingdoms: Journeys Into the Disappearing Religions of the Middle East. New York: Basic Books, 2014.

Sassen, Saskia. Global Networks, Linked Cities. London: Routledge, 2016.

Scott, James C. Against the Grain: Plants, Animals, Microbes, Captives, Barbarians, and a New Story of Civilization. New Haven: Yale University Press, 2017.

Shumsky, Dmitry. Beyond the Nation-State: The Zionist Political Imagination from Pinsker to Ben-Gurion. New Haven: Yale University Press, 2018.

Solomon, Ty. "Ontological Security, Circulations of Affect, and the Arab Spring." Journal of International Relations and Development 21 (2018): 934-58.

Suganami, Hidemi. "British Institutionalists, or the English School, 20 Years On.” International Relations 17, no. 3 (2003): 253-72.

Tilly, Charles. "Cities, States, and Trust Networks: Chapter 1 of Cities and States in World History." Theory and Society 39, no. 3-4 (2010): 265-80.

Tüzgen, Abdullah Enes. "Normative Consensus and Regional Orders: Saudi Reaction to Systemic Crises in the Middle East.” Ph.D. diss., University of Delaware, Newark, 2019.

Vlassopoulos, Kostas. "Between East and West: The Greek Poleis as Part of a World-System." Ancient West and East 6 (2007): 91-111.

Wigal, Donald. Historic Maritime Maps Used for Historic Exploration, 1290-1699. New York: Parkstone, 2000.

Wolters, Oliver W. History, Culture, and Region in Southeast Asian Perspectives. Ithaca, N.Y: Southeast Asia Program Publications, Cornell University, 1999. 